\title{
Comparison of resource and consumer dynamics in Atlantic and Mediterranean streams
}

\author{
Isabel Pardo ${ }^{1} \&$ Maruxa Álvarez \\ Área de Ecología, Universidad de Vigo, 36310 Vigo, Spain \\ ${ }^{1}$ corresponding author: ipardo@uvigo.es
}

\begin{abstract}
This study integrates a wide range of ecological data into a comprehensive framework describing the functional and structural dynamics of streams located under different climatic conditions in Spain. Standing stocks of particulate organic matter, algal biomass and macroinvertebrate communities are examined and compared between Atlantic streams of North-West Spain and Mediterranean temporary streams of the island of Majorca. This data set, which link potential food sources to consumer dynamics, allows explanation for the structural and functional variability exhibited by these two fluvial systems. Results indicate that the differences in the dynamics of community trophic structure of the two types of streams are a reflection of their hydrology and climate characteristics.
\end{abstract}

Keywords: climate, disturbances, trophic structure, Mediterranean streams, Atlantic streams.

\section{RESUMEN}

En este estudio se proporciona un marco conceptual que contrasta la dinámica estructural y funcional de ríos localizados en distintas regiones climáticas existentes en España. Con este propósito se examina un amplio rango de datos de materia orgánica particulada bentónica, de biomasa algal y de comunidades de invertebrados en ríos atlánticos del Noroeste de la Península y en rios temporales Mediterráneos localizados en la isla de Mallorca. Esta serie de datos ecológicos, que relacionan las fuentes de alimentación potenciales con sus consumidores, suministra una base que permite diferenciar no sólo la estructura, si no también el funcionamiento fluvial de ambos sistemas. Los resultados indican que las variaciones en la importancia y dinámica de la estructura trófica en ambos tipos de ríos son un reflejo de sus características hidrológicas y climáticas.

Palabras clave: clima, perturbaciones, estructura trófica, ríos Mediterráneos, ríos Atlánticos.

\section{INTRODUCTION}

Over the last few decades a number of studies have reviewed the structural and functional differences between temperate and Mediterranean aquatic systems (Gasith \& Resh, 1999; ÁlvarezCovelas et al., 2005). These studies point out various gaps in the scientific understanding of Mediterranean systems, mainly in relation to the ecosystem approach. Seasonal patterns of rainfall and temperature across climatic regions have important implications for water availability and landscape structure in fluvial ecosystems. It is well-known that flow dynamics in Atlantic and Mediterranean regions differ strongly, both in quantity and seasonal variation. As a consequen- ce, the two types of stream systems are likely to be affected by different types of disturbances. While flooding is the main physical disturbance occurring in Atlantic areas, both floods and dry periods control Mediterranean streams. Indeed, while most Atlantic streams are permanent, depending on the availability of water and geographical setting, Mediterranean streams are subject to a permanence gradient, from permanent to temporary flow (Álvarez-Covelas et al., 2005). Moreover, Mediterranean temporary streams are subject to a predictable disturbance, drying out most of the summer, thus becoming terrestrial systems, disrupting the biota processes typically driven by water flow (Lake, 2000). When water flow resumes in early autumn, high levels 
of light and temperature and high nutrient concentration initiates algae colonization, thus promoting a rapid increase in biomass (Dieterich \& Anderson, 1998; Álvarez, 2004).

Climate-related parameters also influence the composition, density and phenology of terrestrial vegetation. Differences in riparian forest affect the dynamics of instream allochtonous and autochthonous resources, with the biota being adapted to availability and variability (Cummins et al., 1989). Mediterranean streams have different types of riparian vegetation than temperate Atlantic streams. Mediterranean temporary streams in mountainous areas lack stream-dependent riparian vegetation, thus the stream corridor is primarily composed of terrestrial species with a low interaction with the wet stream channel. Typical Mediterranean riparian vegetation is dominated by evergreen plants, and the ecological significance of leaf longevity has been the subject of many hypotheses (Terradas, 2001), suggesting an adaptation to dry climatic conditions and drought (Cherbuy et al., 2001), scarcity of nutrient resources (Monk, 1966), and resistance to herbivores. In contrast, the riparian corridor of Atlantic temperate streams is dominated by deciduous species with pulses of litterfall coupled with the vegetative seasonal activity. Moreover, ensuring a continuous nutrient supply, some riparian species, e.g. Alder, acquire atmospheric nitrogen from symbiotic relationship with nitrogen fixing organisms in root nodules (Quispel et al., 1993).

Algal communities also differ in Atlantic and Mediterranean streams, reflecting the differences in number of sunny hours in the year, light, temperature and nutrients dynamics that characterize the two stream types. In temporary streams, there is a seasonal sequence of biotic and abiotic regulation of stream assemblages in response to the seasonal events of floods and dry periods (Gasith \& Resh, 1999). Undisturbed temporary streams show a predictable pattern of algae growth in response to the annual variation of the magnitude of temperature and light. However, their importance may be limited by the consumers (Biggs, 1996). In Atlantic temperate streams, dense shading from riparian trees prevents light from reaching the stream bed during warmer seasons, even though springsummer climatic conditions favour algae growth (Hynes, 1970). Therefore, the shorter growing season due to limited solar energy of temperate Atlantic streams compared to similar latitude Mediterranean streams may affect the variation in resource availability. Moreover, this seasonal variation in resources may reflect seasonal differences of macroinvertebrate assemblages, both in structure and function.

\section{Study rationale and objectives}

This study provides data from various streams under different climatic conditions (Atlantic vs Mediterranean) with different flow regimes (permanent vs. temporary), ranging from first order to second order streams. The study was designed to present a useful set of data for a general framework. Therefore, not all factors that might explain the natural variation in energy sources and macroinvertebrates in these systems are tested. Data are provided for macroinvertebrates, periphyton biomass, allochthonous inputs and benthic organic matter storage and retention. These data were recorded on different occasions and in different streams over the last two decades. The data available for these streams are integrated here in an attempt to explain the differences in underlying mechanisms and processes that characterize Atlantic and Mediterranean streams.

\section{METHODOLOGICAL REVIEW}

\section{Study streams}

\section{Atlantic streams: Mera, Deva, Cea and Louro}

The Mera, Deva and Cea are $2^{\text {nd }}$ order streams (sensu Strahler), located in Northwestern Spain. The Mera is subject to continental influence, located at $545 \mathrm{~m}$ a.s.1. (UTM 606000, 475805); The Deva at $624 \mathrm{~m}$ a.s.1. (UTM 558844, 467797) and the Cea at $210 \mathrm{~m}$ a.s.1. (UTM 555018, 466396) (Figure 1). Additional information on 
the sites can be found in Cillero (2001). The Louro localities, LC1 at $320 \mathrm{~m}$ a.s.sl. (UTM 535648467929 ) and LC2 at $120 \mathrm{~m}$ a.s.l. (UTM $533601467749)$, are $1^{\text {st }}$ and $2^{\text {nd }}$ order streams respectively, located in the proximity of the Galician coast in NW Spain. Additional information on the sites may be found in Pardo (1992).

\section{Mediterranean streams}

Most of the data provided for Majorcan streams were obtained from the torrent Gorg Blau (GB), a hardwater, spring-fed stream in the Sant Jordi catchment in the mountainous Northern area of the island (UTM 499564, 441616). The lower spring reach, which was the study site, is located around $500 \mathrm{~m}$ below the springhead and is generally dry during summer (see further details in Álvarez \& Pardo (2005), Álvarez, 2004). The study was conducted in the northern mountainous area of the island (Fig. 1). Some data were also recorded from other sites located on the main axis of the torrent Ternelles (T4 and T5), of which the torrent Gorg Blau is the main tributary. These three sites are located $\sim 1 \mathrm{~km}$ apart (Álvarez, 2004) (Fig. 1).

\section{Climatic data}

Seasonal and annual patterns of precipitation and temperature of the streams have been registered at recording stations of the national Spanish Institute of Metereology. For the Atlantic streams, data were recorded at three stations located in Galicia, one serving as a reference for the continental stream Mera (ID $=1518$, Lugo, colegio Fingoy), and two other for the coastal streams Cea, Deva (ID $=1723$, Ponteareas) and Louro (ID $=1495$, Vigo, Peinador). For the Mediterranean streams, data were recorded on Majorca in the Can Serra gauging station (ID = B745) and Port de Pollensa (ID= B780).

\section{Physico-Chemical measurements}

Current velocity, water depth, and wet channel width were recorded for the studied streams. Current velocity was estimated from three inte- grated recordings taken for one minute on the stream bottom with a velocity-meter (Global Water D-2466, England). Cover percentage of substrate type was determined in an area enclosed by a Surber sampler frame (Álvarez, 2004), or estimated along 20 perpendicular linear transects (Cillero, 2001). Substrate categories were classified by particle size according to the Wentworth Scale (after Cummins, 1962; Minshall, 1984).

\section{Allochthonous Inputs and related processes}

Allochthonous input estimates are only available for the continental Atlantic stream (Mera). Vertical litterfal was determined from 5 traps randomly placed over the stream. Each trap consisted of a $1 \mathrm{~m}^{2}$ frame with a funnel shaped net of $1 \mathrm{~mm}-\mathrm{mesh}$, tied with a rubber band to allow collection of samples. The traps were placed randomly, suspended $\sim 1 \mathrm{~m}$ above the river surface from surrounding trees (see Cillero et al., 1999). All samples from each trap were kept separately. After collection, each leaf litter was dried $\left(80^{\circ} \mathrm{C}, 20 \mathrm{~h}\right)$, sorted and weighed to the nearest 0.0001 g. Samples were collected monthly from June 1998 to June 1999.

Benthic particulate organic matter standing stock (BPOM) was obtained for 3 Atlantic streams (Mera, Cea, Deva) and for the Torrent Gorg Blau. After removing all organisms, organic detritus was separated, dried at $60{ }^{\circ} \mathrm{C}$ for $48 \mathrm{~h}$ and weighed to estimate dry weight of BPOM. Samples were taken on two occasions (December and June) within a year period.

Retention characteristics were measured for 3 Atlantic streams (Mera, Cea, Deva). Plastic strips were used as set of artificial leaves to measure retention capacity (following Webster et al., 1994). At each site, 100 plastic strips $(4 \times 8.5 \mathrm{~cm})$ were released across the width of the channel at the upstream end of the studied reach. Thirty minutes after release, the entire reach was examined for strips retained, and the number of strips and distance travelled were recorded. Three releases were made on each sampling occasion. Leaf retention was adjusted to an exponential model, following Lamberti \& Gregory (1996). This procedure allowed estima- 


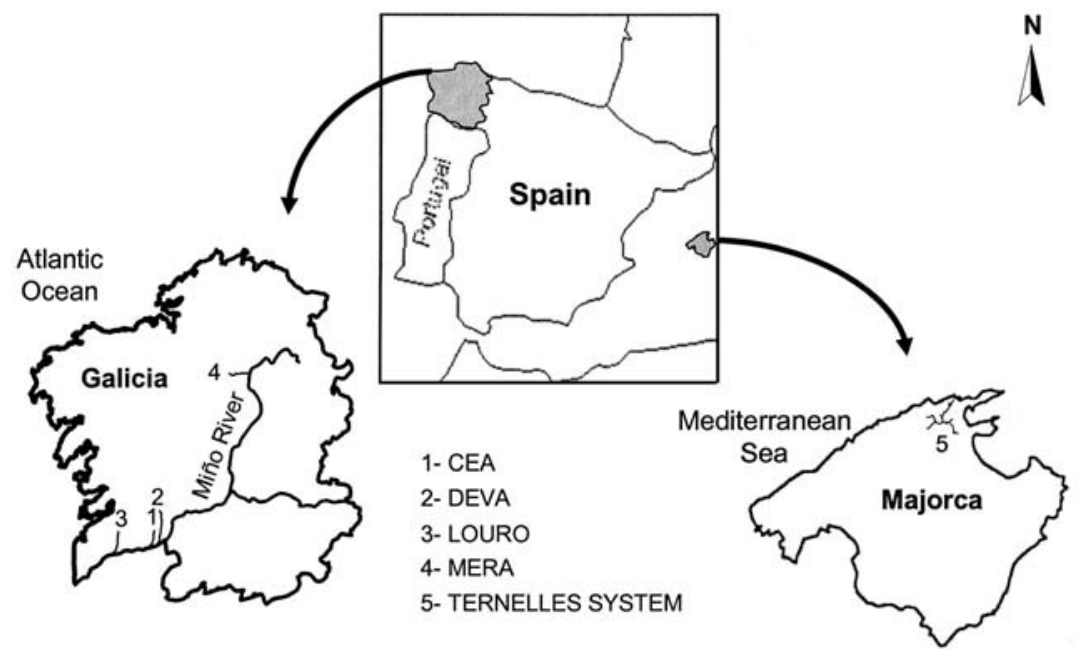

Figure 1. Location of the study streams. Atlantic streams are located in Galicia (NW Spain) and the Mediterranean streams in the island of Majorca. Localización de los ríos estudiados. Los ríos atlánticos se localizan en Galicia (NO España) y los ríos mediterráneos en la isla de Mallorca.

tion of the instantaneous retention rate and average distance travelled by a specific particle in each stream. Samples were collected monthly from June 1998 to June 1999.

\section{Periphyton organic matter}

Data on periphyton biomass are available for 3 Atlantic (Cea, Deva and Mera) and three Mediterranean (GB, T4, T5) streams. Periphyton samples (examined by analysis of chl $a$ ) were taken from individual rocks collected from each site. From each rock, an area of $8.05 \mathrm{~cm}^{2}$ was scraped with a chisel and a nylon toothbrush. Chl $a$ was extracted in $90 \%$ acetone in darkness and at low temperature and measured spectrophotometrically (Unicam UV/VIS UV4 Spectrometer, Cambridge, UK). Values were determined using the equations described in Lorenzen (1967).

\section{Macroinvertebrate sampling}

Data on annual patterns of macroinvertebrates are available for 2 Atlantic $(\mathrm{LC} 1, \mathrm{LC} 2)$ and one Mediterranean (GB) stream. Quantitative samples were collected with a Surber sampler $\left(0.09 \mathrm{~m}^{2}\right)$ of $500 \mu \mathrm{m}$ in the Atlantic streams and of $100 \mu \mathrm{m}$ mesh size in the Mediterranean stream. Small invertebrates (ostracoda and copepo- da), were not considered in the analysis. Samples were preserved in the field in $10 \%$ formaldehyde and sorted in the laboratory. All invertebrates were picked from the fractions $>1 \mathrm{~mm}$. However, when the volume of sample was large, smaller fractions were sub-sampled. Macroinvertebrates were identified to genus, family or species level under a dissecting microscope. Each taxa was assigned to a functional feeding group (FFG) based on mouthpart morphology and feeding behavior following Cummins (1973) and supported by examination of the gut contents of the dominant taxa.

\section{STREAMS CHARACTERIZATION}

\section{Geomorphic setting: geography, geology and climate}

The Atlantic streams are located at medium elevations in North-West Spain (Galicia) (Fig. 1). They are relatively small (annual mean across streams $\pm 1 \mathrm{SE}=2.1 \pm 0.6 \mathrm{~m}$ wide, $24.4 \pm 4.5 \mathrm{~cm}$ deep) and are characterized by a typical sequence of riffles and pools. The substrate is primarily composed of variously sized cobbles and pebbles placed on top of gravel and coarse sand (Pardo, 1992; Cillero 2001) 
Table 1. Selected physico-chemistry parameters at the study streams. Values represent the mean for an annual flow period (1986-87 in the Atlantic stream Louro; 1998-1999 in the Atlantic streams Mera, Cea and Deva; 2000-2001 in the Mediterranean streams). Parámetros fisicoquímicos de los ríos estudiados. Los valores representan los valores medios para un periodo hidrológico anual (1986-87 en el río atlántico Louro; 1998-1999 en los ríos atlánticos Mera, Cea y Deva; 2000-2001 en los ríos mediterráneos).

\begin{tabular}{|c|c|c|c|c|c|c|c|c|c|c|c|c|}
\hline & STREAM & $\begin{array}{c}\text { Temperature } \\
\left({ }^{\circ} \mathrm{C}\right)\end{array}$ & $\mathrm{pH}$ & $\begin{array}{l}\text { Conductivity } \\
\qquad\left(\mu \mathrm{S} \mathrm{cm}{ }^{-1}\right)\end{array}$ & $\begin{array}{l}\text { Oxygen } \\
\left(\mathrm{mg} \mathrm{L}^{-1}\right)\end{array}$ & $\begin{array}{l}\text { Flow } \\
\left(\mathrm{L} \mathrm{s}^{-1}\right)\end{array}$ & $\begin{array}{c}\text { Water } \\
\text { depth } \\
(\mathrm{cm})\end{array}$ & $\begin{array}{c}\text { Channel } \\
\text { width } \\
\text { (cm) }\end{array}$ & $\begin{array}{c}\text { Boulder } \\
\text { (\%) }\end{array}$ & $\begin{array}{c}\text { Stone- } \\
\text { Pebble } \\
(\%)\end{array}$ & $\begin{array}{c}\text { Gravel } \\
(\%)\end{array}$ & $\begin{array}{c}\text { Sand-silt } \\
(\%)\end{array}$ \\
\hline \multirow[t]{4}{*}{ ATLANTIC } & MERA & 13.4 & 6.2 & 41.0 & 9.6 & 113.8 & 25.0 & 190.8 & 21.5 & 29.2 & 14.4 & 34.8 \\
\hline & CEA & 14.7 & 6.0 & 24.3 & 9.9 & 127.5 & - & - & 53.5 & 21.8 & 7.9 & 16.9 \\
\hline & DEVA & 13.3 & 5.7 & 18.9 & 9.6 & 310.0 & 36.8 & 214.6 & 25.1 & 43.2 & 5.9 & 25.8 \\
\hline & mean & 13.8 & 6.0 & 28.1 & 9.7 & 183.8 & 30.9 & 202.7 & 33.4 & 31.4 & 9.4 & 25.8 \\
\hline \multirow[t]{4}{*}{ MEDITERRANEAN } & GB & 16.9 & 7.4 & 763.2 & 9.2 & 8.9 & 10.8 & 87.7 & 12.8 & 56.4 & 19.7 & 11.1 \\
\hline & $\mathrm{T} 4$ & 18.3 & 7.6 & 1104.9 & 9.6 & 3.3 & 5.9 & 132.9 & 49.5 & 29.9 & 16.4 & 4.1 \\
\hline & $\mathrm{T} 5$ & 13.8 & 7.9 & 709.4 & 10.2 & 13.3 & 7.4 & 202.6 & 70.6 & 19.0 & 9.4 & 1.0 \\
\hline & mean & 16.3 & 7.6 & 859.2 & 9.7 & 8.5 & 8.0 & 141.1 & 44.3 & 35.1 & 15.1 & 5.4 \\
\hline
\end{tabular}

(Table 1). The parent rock is siliceous granite, reflected in waters of a slightly acidic character $(\mathrm{pH}$ mean of streams annual means of 6.1) and low salt content (electric conductivity mean of streams annual means of $42.0 \mu \mathrm{S} \mathrm{cm}-1$ ) (Table 1) (see Pardo, 1995) for further details on the chemistry dynamics of the Louro stream sites). The climate is Atlantic temperate, characterized by mild to cool winters and warm summers, although the temperature and precipitation are influenced by a coastal -inland gradient of continentality (Table 2). Mean air temperature for a 24-year period was
$13.7 \pm 1{ }^{\circ} \mathrm{C}(1975-98)$ (mean monthly temperature average for each year across streams \pm 1SE) (Table 2). Mean annual precipitation for the same period was $1449.7 \mathrm{~mm}( \pm 265.0)$ (Table 2). Generally, precipitation in Atlantic streams is higher in autumn and winter months reducing progressively through spring and summer (Fig. 2). However, these streams receive relatively constant year round precipitation, which, for the mentioned period, was reflected in the high average number of days with rain (mean across streams $\pm 1 \mathrm{SE}=152 \pm 4$ days) and the low percentage contribution of monthly
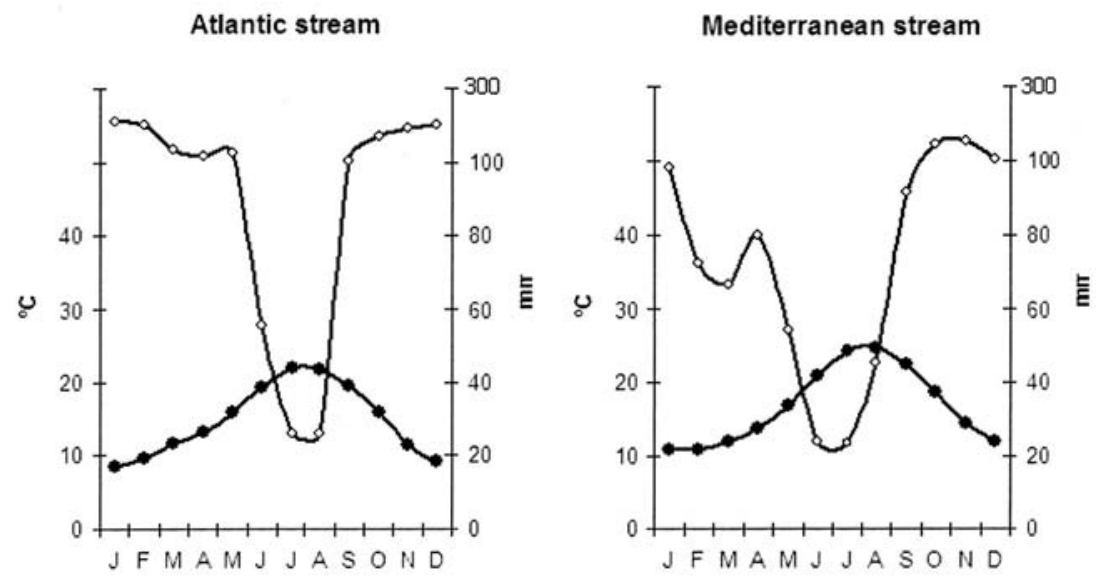

Figure 2. Climate diagrams for the coastal Atlantic streams (Ponteareas) and for the Mediterranean streams (Can Serra, Pollensa). Graph scales follow Molles (1999). Diagramas climáticos de los ríos costeros atlánticos (Puenteareas) y de los ríos Mediterráneos (Can Serra, Pollensa). Las escalas de los gráficos siguen a Molles (1999). 
Table 2. Climate characteristics of the study streams. See text for further details. Características climáticas de los ríos estudiados. Ver el texto para más detalle.

\begin{tabular}{|c|c|c|c|c|}
\hline & \multicolumn{3}{|c|}{ Atlantic } & \multirow{3}{*}{$\begin{array}{c}\text { Mediterranean } \\
\text { GB }\end{array}$} \\
\hline & \multirow{2}{*}{$\begin{array}{l}\text { Continental } \\
\text { Lugo }\end{array}$} & \multicolumn{2}{|c|}{ Coastal } & \\
\hline & & Ponteareas & Louro & \\
\hline \multicolumn{5}{|l|}{ Precipitation } \\
\hline Mean annual value & 991.5 & 1448.1 & 1909.5 & 895.7 \\
\hline SE & 40.3 & 63.5 & 63.5 & 54.9 \\
\hline Inter-anual variation (CV) & 0.78 & 0.89 & 0.85 & 0.92 \\
\hline SE & 0.05 & 0.04 & 0.04 & 0.04 \\
\hline Range (inter-annual) & $0.45-1.33$ & $0.48-1.34$ & $0.50-1.41$ & $0.59-1.34$ \\
\hline Maximun monthly contribution & $4.9 \%$ & $5.1 \%$ & $4.5 \%$ & $12.0 \%$ \\
\hline SE & $0.3 \%$ & $0.3 \%$ & $0.2 \%$ & $0.7 \%$ \\
\hline$\%$ of days with rain per year & $41.2 \%$ & $39.9 \%$ & $43.5 \%$ & $15.7 \%$ \\
\hline Mean number of days with rainper year & 150 & 146 & 159 & 57 \\
\hline $\mathrm{SE}$ & 4 & 8 & 3 & 3 \\
\hline \multicolumn{5}{|l|}{ Temperature } \\
\hline Annual mean & 12.6 & 14.8 & 13.8 & 17.0 \\
\hline SE $\quad$ & 0.2 & 0.2 & 0.1 & 0.1 \\
\hline Inter-anual variation $(\mathrm{CV})$ & 0.4 & 0.3 & 0.3 & 0.3 \\
\hline
\end{tabular}

precipitation to the annual totals (mean across streams $\pm 1 \mathrm{SE}=4.9 \pm 0.2 \%$ ) (Table 2$)$.

Majorca is the largest $\left(3640.16 \mathrm{~km}^{2}\right)$ of the Balearic Islands, located at a distance of $167 \mathrm{~km}$ off the East coast of the Iberian Peninsula. The studied Mediterranean stream reaches are located in mountain areas, at relatively low altitude $(125-150 \mathrm{~m})$. Streams on the island of Majorca are not found at higher elevation than around $300 \mathrm{~m}$ a.s.1. The studied Mediterranean streams are small (annual mean across stream reaches \pm $1 \mathrm{SE}=1.4 \pm 0.1 \mathrm{~m}$ wide, $8.0 \pm 0.5 \mathrm{~cm}$ deep) (Table 1). Percentages of dominant substrate differed among streams. Substrate composition change among stream reaches, but mainly includes stones, pebbles and boulders (Table 1). However, in some streams (see for example T5), the stream bed is highly affected by calcite precipitation, which is reflected in an almost continuous layer of tightly consolidated substrate (i.e., bedrock) (Álvarez, 2004). The catchment geology is rather complex and largely consists of sandstone, limestone and dolomite (GarcíaAvilés, 1990). As expected, the geology is reflected in the chemistry of the waters, which are high in $\mathrm{pH}$ (annual mean across stream reaches \pm $1 \mathrm{SE}=7.6 \pm 0.1)$ and high in electric conductivity $\left(859.2 \pm 47.4 \mu \mathrm{S} \mathrm{cm}^{-1}\right)$ (Table 1). Moreover, these mountain streams are fed by karstic aquifers with high infiltration capacity, which strongly affects the hydrology of these streams.

The island of Majorca has a typical Mediterranean climate with warm to hot temperatures all year round (mean temperature for 1962-1991, was $17.0 \pm 0.1{ }^{\circ} \mathrm{C}$ ) and low annual rainfall (for 1975-1998, was 895.7 $\pm 54.9 \mathrm{~mm}$ ) (Table 2). Moreover, most of the precipitation over Majorca falls as torrential rain, which, for the mentioned 24-year period, is reflected in the low average number of days with rain ( $57 \pm 3$ days), the high percentage contribution of monthly precipitation to the annual total $(12.0 \pm 0.7 \%)$ and in the relatively high average CV $(0.92 \pm 0.04)$ (Table 2$)$.

\section{Hydrology and water temperature}

The high precipitation levels and high runoff that characterize the Atlantic catchments, generates a landscape drained by hundreds of small, fast flowing streams of a permanent character. Annual flow patterns in Atlantic streams usually show maximum peaks in autumn and winter (with frequent floods), progressive reduction towards spring and summer, and minimum discharges occurring in September (Fig. 3) (Pardo, 1995; 2000). 


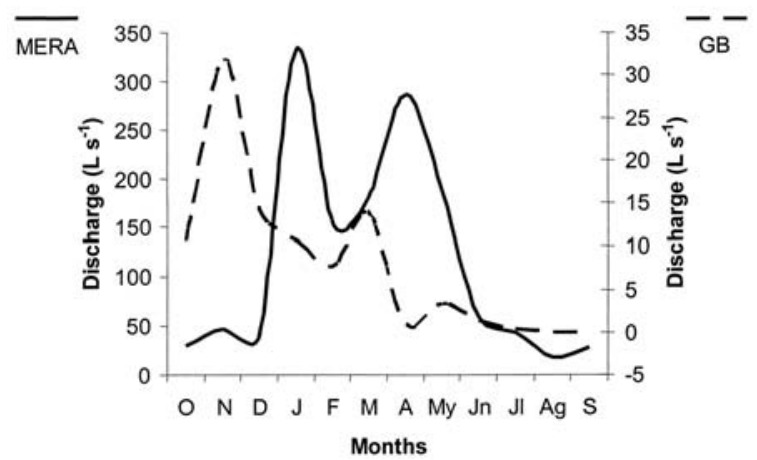

Figure 3. Discharge for the Atlantic Mera stream and the Mediterranean torrent Gorg Blau for an hydrologic year, from October to July/August $(\mathrm{O}=$ October, $\mathrm{S}=$ September, $\mathrm{N}=$ November, $\mathrm{D}=$ December, $\mathrm{J}=$ January, $\mathrm{F}=$ February, $\mathrm{M}=$ March, A = April, M = May, Jn = June, J1 = July, Ag = August). Caudales del atlántico río Mera y del torrente mediterráneo Gorg Blau durante un año hidrológico, desde octubre a Julio/agosto $(O=$ octubre, $S=$ septiembre, $N=$ noviembre, $D=$ diciembre, $J=$ enero, $F=$ febrero, $M=$ marzo, $A=$ abril, $M=$ mayo $J n=$ junio, $J l=$ julio, $A g=$ agosto).

The Mediterranean stream, showed a delayed response to rainfall patterns compared to the Atlantic streams (Fig. 2 \& Fig. 3), which may be attributed to the hydrogeologic features of the karstic aquifers (Del Rosario \& Resh, 2000). Moreover, as occurs in many Mediterranean environments (Vidal-Albarca et al., 1992; Cattaneo et al., 1995), the negative hydrologic balance during the warm dry summer interrupts the stream flow (Fig. 3). For example, from 1999 to 2000 (considered as an average hydrological year), the flow period of the Gorg Blau lasted for about 10 months, starting with high discharges in autumn (end of October) and drying out completely in late-July (Fig. 3).

As expected, discharge in the streams varied over time and space by several orders of magnitude during the years of study (e.g., ranged from 0.4 to $31.8 \mathrm{~L} \mathrm{~s}^{-1}$ in the torrent Gorg Blau and from 57 to $659.1 \mathrm{~L} \mathrm{~s}^{-1}$ in the Mera river) (Table 2, Fig. 3). Water temperature was also variable among streams and time (e.g., ranged from 7.4 to $17.9{ }^{\circ} \mathrm{C}$ in the Mera river and from 12.6 to $29.6{ }^{\circ} \mathrm{C}$ in the torrent Gorg Blau) (Table 2). Other studies which have compared temporary vs permanent streams in geographically close areas, provided greater water temperature range for permanent streams (e.g., Dieterich \& Anderson, 1998). In our comparison, the wider water temperature range corresponded to the temporary stream, fact that can be clearly attributed to the Mediterranean climate influence.

\section{RIPARIAN INFLUENCES ON THE STREAM}

In Atlantic streams, riparian vegetation is usually dominated by Alnus glutinosa L., Betula alba L., and Fraxinus excelsior L., mixed with oak species (Quercus robur L., Q. pyrenaica Willd.). However, Alder is the dominant tree species in small, low-gradient streams. The riparian canopy in these streams is well-developed along the channel, and usually shade the stream completely. Alder asymmetric distribution of tree branches creatings a greater production of leaves towards the stream (Cillero et al., 1999).

The riparian vegetation of Majorcan streams is composed of the typical Mediterranean terrestrial vegetation of holm-oak (Quercus ilex L.) and Aleppo pine (Pinus halepensis Miller), the latter dominating on southern slopes. These streams usually have wide active channels. Despite larger variations in flow over the years, the flow is mainly concentrated in the center of the channel. This reduction in the wet area towards the center of the channel allows the access of direct light to the stream bottom.

\section{Litterfall}

Litter inputs to the Atlantic Mera stream were $730.0 \mathrm{~g} \cdot \mathrm{m}^{-2} \cdot \mathrm{yr}^{-1}$, and the vegetative-seasonal cycle of various species gives rise to a distinct litterfall seasonal pattern of leaves and fruits (Cillero et al. 1999), which was apparent in these riparian forests. Leaf shed of the dominant riparian alder showed a bimodal pattern with maximum values in July and November (Cillero et al., 1999). However, leaf shed from chestnut and oak was unimodal, beginning in October, and reaching a maximum for chestnut in November, and for oak in December. The input of reproductive structures was highest in 
February-March due to higher amounts of alder flowers, while no clear seasonal patterns were observed for wood and debris fall.

Although data are not available for the studied Mediterranean streams, studies conducted in other Mediterranean streams (e.g., Cherbuy et al., 2001; Bussotti et al., 2003; Bellot et al. 1992) show that evergreen holm-oak (Q. ilex) shed leaves throughout the year, with recorded maximum values between April and July. This more substantial inputs occur at a time of increasing temperatures and progressively reduced water levels in the Majorcan streams. Moreover, other studies conducted in central Italy (Bussotti et al., 2003) provided annual litter inputs values for holm-oak in xeric and mesic forests of 485 and $694 \mathrm{~g} \mathrm{~m}^{-2}$ respectively, which may be comparable to the litter input to the studied Majorcan streams.

\section{Benthic organic matter retention and storage}

Small Atlantic streams are generally very retentive due to a diversity of in-stream structures such as tree roots and dominance of coarse substrates such as stones and blocks. In the smallest channel of the Cea ( $2 \mathrm{~m}$ wide) and under low discharge ranges $\left(<0.31 \mathrm{~m}^{3} \mathrm{~s}^{-1}\right)$, released plastic strips were retained within the first $7.1 \mathrm{~m}(1 / \mathrm{k})$. However, in wider channels of the Mera and Deva (around $3 \mathrm{~m}$ wide) and under higher discharges (up to $\left.0.72 \mathrm{~m}^{3} \mathrm{~s}^{-1}\right)$, the mean distance travelled by the strips increased to $16.5 \mathrm{~m}$ (Cillero, 2001).

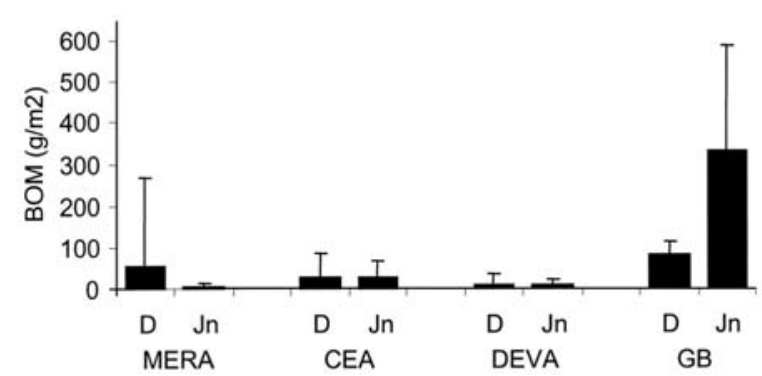

Figure 4. Benthic organic matter (BOM) for the three Atlantic streams and for the Mediterranean stream (GB). The graph shows mean values ( $\pm 1 \mathrm{SE})$. D = December samples; Jn= June samples. Materia orgánica bentónica (MOB) para los 3 ríos atlánticos y el río mediterráneo (GB). Los gráficos muestras los valores medios ( $\pm 1 E E)$. $D=$ muestras de diciembre; $J_{n}=$ muestras de junio.
BPOM estimated in the 3 continental Atlantic streams ranged from a mean of 5.2 (in the Deva in June) to $52 \mathrm{~g} \mathrm{~m}^{-2}$ (in the Mera in December) (Cillero, 2001), representing between 0.7 and $7 \%$ of total annual inputs to the streams. In the Mera stream, BPOM follows the predicted pattern of higher standing stocks in autumn (December) (Fig. 4) before leaves have been processed completely. However, other streams (Fig. 4) (i.e., Cea and Deva) show only a slight difference between autumn (December) and summer (June). In Atlantic streams, spring-summer leaf processing of different riparian and terrestrial species occurs in less than 2 months. In these streams, decay rate is mainly explained by greater nutritional value and softer consistency of green leaves entering the stream, as well as to active processing by shredders. Autumn-winter processing is also similarly fast, influenced by higher frequency and intensity of flow disturbance and by physical fragmentation of leaf packs (López et al., 1997; López et al., 2001).

In the torrent Gorg Blau, mean particulate organic matter standing stock over the studied flow period was $157.7 \pm 33.9 \mathrm{~g} \mathrm{AFDM} \mathrm{m}^{-2}$ (Álvarez, 2004). On a seasonal basis, this temporary stream had from 7.3 (December) to 8.5 (June) times more BPOM than the Atlantic streams (Fig. 4). Several factors may explain these differences. Moderate flow-related physical forces, in combination with channel characteristics may contribute to higher retention of BPOM in the Mediterranean streams. Therefore, in spite of their shallowness and the near absence of retentive structures in the channel, temporary streams are very retentive during stable flow conditions. Only major floods, which mainly occur in autumn at the beginning of the flow period seem to be able to mobilise litter packs accumulated on the dry streambed during summer. Moreover, invertebrate leaf consumption that in turn is influenced by litter quality may influence stream organic matter standing stocks.

Although research on leaf decomposition has not been conducted in Majorcan streams, other studies have observed that the leathery and lownutrient leaves of the evergreen holm-oak (Q. ilex) decompose slower than those of other 
species (Fano et al. 1988; Gessner \& Chauvet, 1994; Schwarz \& Schwoerbel, 1997). Additionally, other experimental studies on leaf decomposition in temporary streams attribute the lower breakdown of leaves to the lower microbial activity occurring in these systems due to the time lag required for the development of the microflora after submersion (e.g. Maamri et al., 1997). Rapp \& Leonardi (1988) found that under Mediterranean climatic conditions, Holm-oak leaves entering the stream in summer required a minimum conditioning time of 5 months, and the leaves completed their decomposition only during the following flow season, thus also favouring BPOM accumulation in the stream bed. This should explain the stable values of BPOM found in the torrent Gorg Blau over the studied flow period (Álvarez, 2004).

\section{PRIMARY PRODUCERS: PERIPHYTON BIOMASS}

Overall, the Mediterranean temporary streams had 10 times more periphyton biomass (mean chl $a$ over three streams $\pm 1 \mathrm{SE}=49.6 \pm 28.28 \mathrm{mg}$ $\mathrm{cm}^{-1}$ ) than the Atlantic streams (mean over three streams $\left.\pm 1 \mathrm{SE}=4.6 \pm 28.8 \mathrm{mg} \mathrm{cm}^{-1}\right)$ (Fig. 5).

Similar to other forested temperate streams around the world, values of chl $a$ in the Atlantic streams remained relatively constant over time (Rosemond, 1994). However, chl a reached higher values in spring (e.g., $5.9 \mathrm{mg} \mathrm{m}^{-2}$ in May in Mera stream) and lower values in winter (e.g., $1.5 \mathrm{mg} \mathrm{m}^{-2}$ in January in Mera stream), coinciding with the less favourable season for periphyton growth in these streams (Bott et al., 1978; Rounick \& Gregory, 1981) (Fig. 5). Moreover, higher values of benthic biomass in some of the Atlantic streams (Deva) was inversely related to flow, with higher values corresponding to the Cea and Mera streams with lower annual discharge amplitudes (Cillero, 2001). These results are similar to results reported by other studies (Sabater et al., 1998; Elosegui \& Pozo, 1998; Lohman, 1992).

In Mediterranean streams, maximum values of periphyton chl $a$ were reached at the begin-
Table 3. Components of taxonomic richness in two Atlantic streams (LC1 \&LC2) and one Mediterranean stream (GB). Componentes de la riqueza taxonómica en dos ríos atlánticos (LC1 y LC2) y en un río mediterráneo $(G B)$.

\begin{tabular}{lcrrr}
\hline \multicolumn{1}{l}{ Taxonomic Level } & LC2 & LC1 & GB \\
\hline \multirow{2}{*}{ Species } & Total Richness & 108 & 76 & 41 \\
& Annual average & 50 & 28 & 31 \\
& $\quad \pm$ 1SE & 3 & 2 & 1 \\
Genus & Total Richness & 80 & 61 & 40 \\
Family & Total Richness & 57 & 42 & 34 \\
order/class & Total Richness & 16 & 18 & 14 \\
\hline
\end{tabular}

ning of the flow period (e.g., $43.4 \mathrm{mg} \mathrm{m}^{-2}$ in Octuber in the torrent Gorg Blau) and subsequently declined towards the end of the flow period, which has been attributed to grazing (Álvarez, 2004) (Fig. 5). Depending on the strength of grazers-periphyton interactions, Mediterranean streams showed a gradient of periphyton availability. Streams with highest values of chl $a$ correspond to those with lowest grazer density (e.g., T5), and values of chl $a$ were relatively low in streams highly affected by grazing (e.g., GB) (Fig. 5).

\section{SECONDARY PRODUCERS: MACROINVERTEBRATES}

\section{Taxonomic composition}

Patterns in macroinvertebrate density and community composition, examined using nonmetric multidimensional scaling (MDS) on the Bray Curtis similarity matrix of macroinvertebrate densities (at family level), showed a clear separation in the ordination diagram of permanent Atlantic (2 sites in the Louro stream, LC1 and LC2) and temporary Mediterranean streams (one site in the Gorg Blau) (Fig. 6). Macroinvertebrate density was thirty times higher in Gorg Blau (mean annual $\pm 1 \mathrm{SE}=25803$ ind $\mathrm{m}^{-2}$ \pm 4257 ) than in $\mathrm{LC} 1$ (mean $\pm 1 \mathrm{SE}=850$ ind $\mathrm{m}^{-2}$ $\pm 236)$, the two sites most clearly differentiated by their taxa composition (Fig. 6, Table 3). Invertebrate families responsible for $>90 \%$ of dissimilarity between the Gorg Blau (GB) and the two Atlantic stream sites together (LC1, 

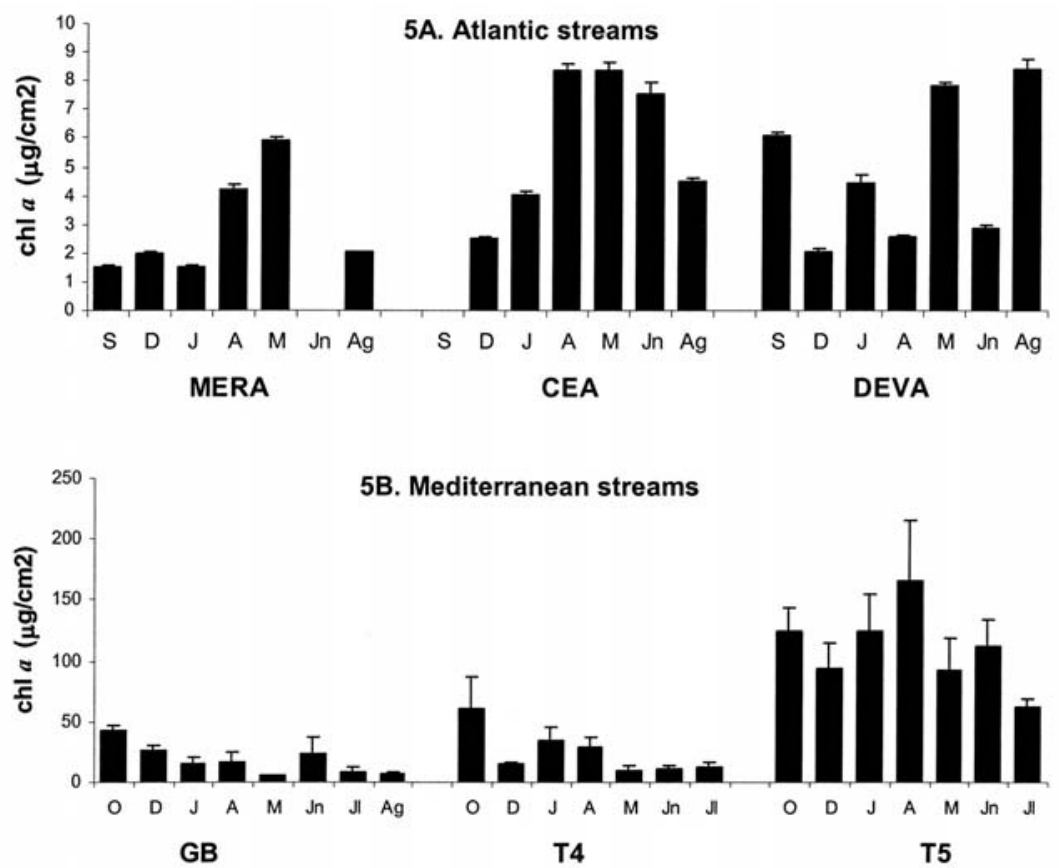

Figure 5. Dynamics of periphyton chl $a$ in three Atlantic (5A) and three Mediterranean (5B) streams for an hydrological year, from September/October to July/August. The graph shows mean values $+1 \mathrm{SE} .(\mathrm{O}=$ October, $\mathrm{S}=\mathrm{September,} \mathrm{D}=\mathrm{December}, \mathrm{J}=\mathrm{January}$, $\mathrm{A}=$ April, $\mathrm{M}=$ May, $\mathrm{Jn}=\mathrm{June}, \mathrm{Jl}=\mathrm{July}, \mathrm{Ag}=$ August). Dinámica de la Cl a del perifiton en los tres ríos atlánticos (5A) y en los tres mediterráneos (5B) para un año hidrológico, de septiembre/octubre a julio/agosto. Los gráficos muestras los valores medios +1EE. $(O=$ octubre, $S=$ septiembre, $D=$ Diciembre, $J=$ enero, $A=$ abril, $M=$ mayo, $J n=j u n i o, J l=j u l i o, A g=a g o s t o)$.

LC2), from a total of 70 families recorded (SIMPER analysis, programme PRIMER), were: Hydrobiidae, Caenidae, Ancylidae, Physidae, Glossosomatidae and Gammaridae (more abundant in GB), and Nemouridae and Psychomyiidae (more abundant in the Atlantic streams). These eight families contributed $32.6 \%$ to the dissimilarly between the stream communities (total dissimilarity $=68.73 \%$ ).

In general, permanent streams are inhabited by a richer fauna than temporary streams (Table 3). Taxa richness of macroinvertebrates, with similar identification level for insects, were compared in two permanent headwater Atlantic streams (LC2 and LC1) and the torrent Gorg Blau for a hydrological year. On an annual basis, total taxa richness per sampling area was considerably lower in GB (41) than in the other two sites (Table 3). However, such large variation was lower when comparing taxa at the family level table 3). These differences could be attributed to the low species-richness within groups that characterize the Majorcan streams, with most genera represented by a single species (Álvarez, 2004). In addition, average macroinvertebrate taxa richness (mostly family level) for the torrent Gorg Blau (31) was similar to that in LC1 (28), although somewhat lower than in LC2 (50). LC1 is a headwater Atlantic stream comparable in size to GB, which explains the lower taxa richness in comparison to LC2, an Atlantic second order stream with higher habitat heterogeneity and with a more developed riparian corridor (Pardo, 1992). Moreover, although GB and LC1 show similar average macroinvertebrate taxa richness, the total taxa richness was higher in $\mathrm{LC} 1$, indicating that the Atlantic stream has a higher replacement of taxa through time. Therefore, rather than attributing these differences to the insularity of GB, they may be attributed to the hydrologic regime of the compared streams. In fact, Vivas (2003) found that in a temporary spring-fed stream of Southeast Spain, total taxa richness was between 27 and 32 (overall total 45 ); values comparable to the totals of $27-34$ 
(overall 41) observed in the torrent Gorg Blau. These results suggest that spring feed, temporary streams on the island of Majorca have taxa richness comparable to similar streams on the mainland. However, their temporality may explain the lower species richness than similar small permanent headwaters streams in Atlantic climate, which in turn may allow a longer growing season for aquatic insects and the occurrence of taxa with different species traits (i.e., longer life cycles) (Delucchi, 1989; Williams, 1996). Even though many studies have found a remarkable similarity between fauna in temporary stream habitats and fauna found in nearby permanent streams (Boulton \& Lake, 1992; Feminella, 1996). Others have noted rather distinct differences between permanent and temporary forest streams (Delucchi, 1988; Dieterich \& Anderson, 2000; Muñoz, 2003).

MDS ordination indicated that differences in community composition between sites were greater than temporal differences (Fig. 6). However, there was a clear intra-annual variation in community structure in the GB, (Fig. 6), which has been shown to reflect its temporality, with distinct signs of succession after the summer dry period (Álvarez, 2004).

\section{Functional organization of the macroinvertebrate communities}

On an annual basis, the relative importance of all FFG was significantly different between the three streams; Atlantic streams (LC1 and LC2) and torrent GB (ANOVA, $\mathrm{p}<0.001$ ). The Mediterranean spring-fed stream consisted largely of collector-gatherers $(38 \%)$ and scrapers $(45 \%)$ followed by filter-feeders $(9.7 \%)$, shredders $(4 \%)$ and predators (3.4\%). However, in the permanent Atlantic streams, mean collectorgatherers and scrapers comprised $(17.3 \pm 2 \%)$ and $(26 \pm 2.8 \%)$, respectively. Filter-feeders $(15 \pm 2.5 \%)$ were better represented in Atlantic streams, and shredders $(32.3 \pm 4 \%)$ and predators $(9.7 \pm 1 \%)$ were more abundant.

In the permanent Atlantic streams (LC1 and LC2) relative abundances of FFGs showed significant temporal patterns, with most FFG

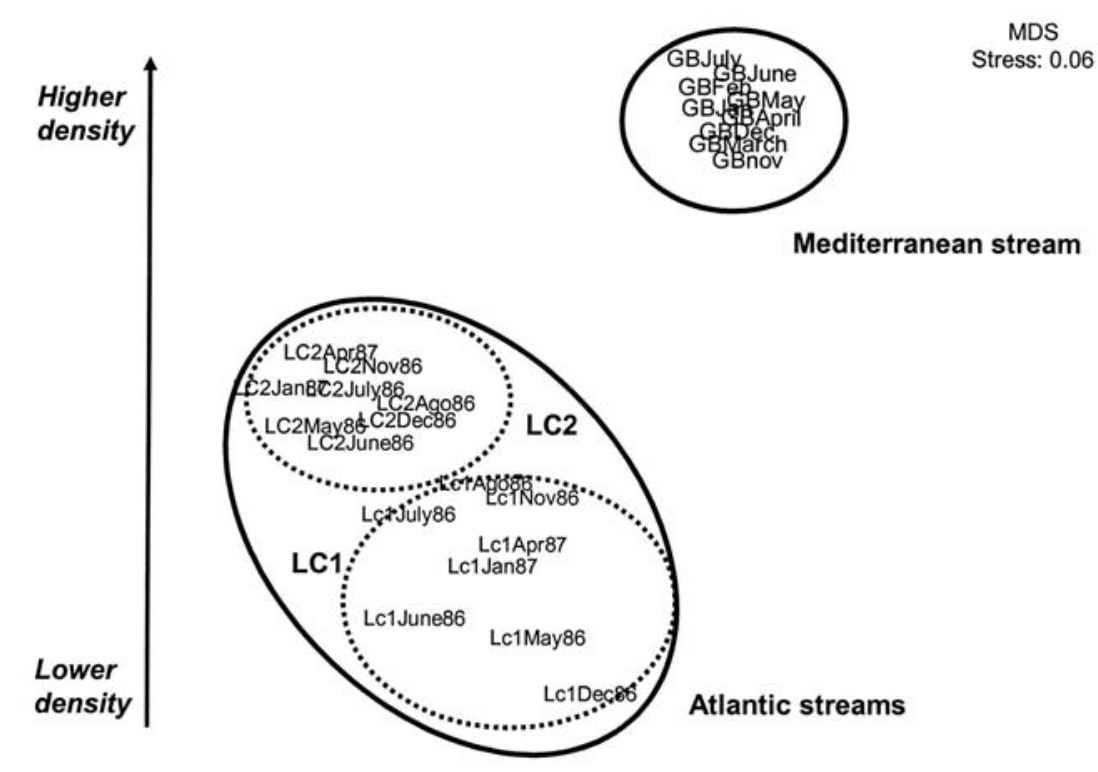

Figure 6. MDS ordination plot of monthly samples of invertebrate assemblages. Analysis were based on $\arcsin (\sqrt{\mathrm{x}})$-transformed abundances of the dominant taxa and a Bray-Curtis similarity matrix. Lines have been drawn around samples from the same stream (and thus, with similar taxa compositions) as an aid to visual interpretation (see text). Ordenación MDS de las muestras mensuales de comunidades de invertebrados bentónicos. Los análisis se basan en las abundancias de los taxones dominantes transformadas mediante el arcoseno $(\sqrt{x})$, e indice de similitud de Bray-Curtis. Las líneas agrupan muestras de un mismo río (y por tanto con similar composición taxonómica) para ayudar en la interpretación visual (ver texto). 

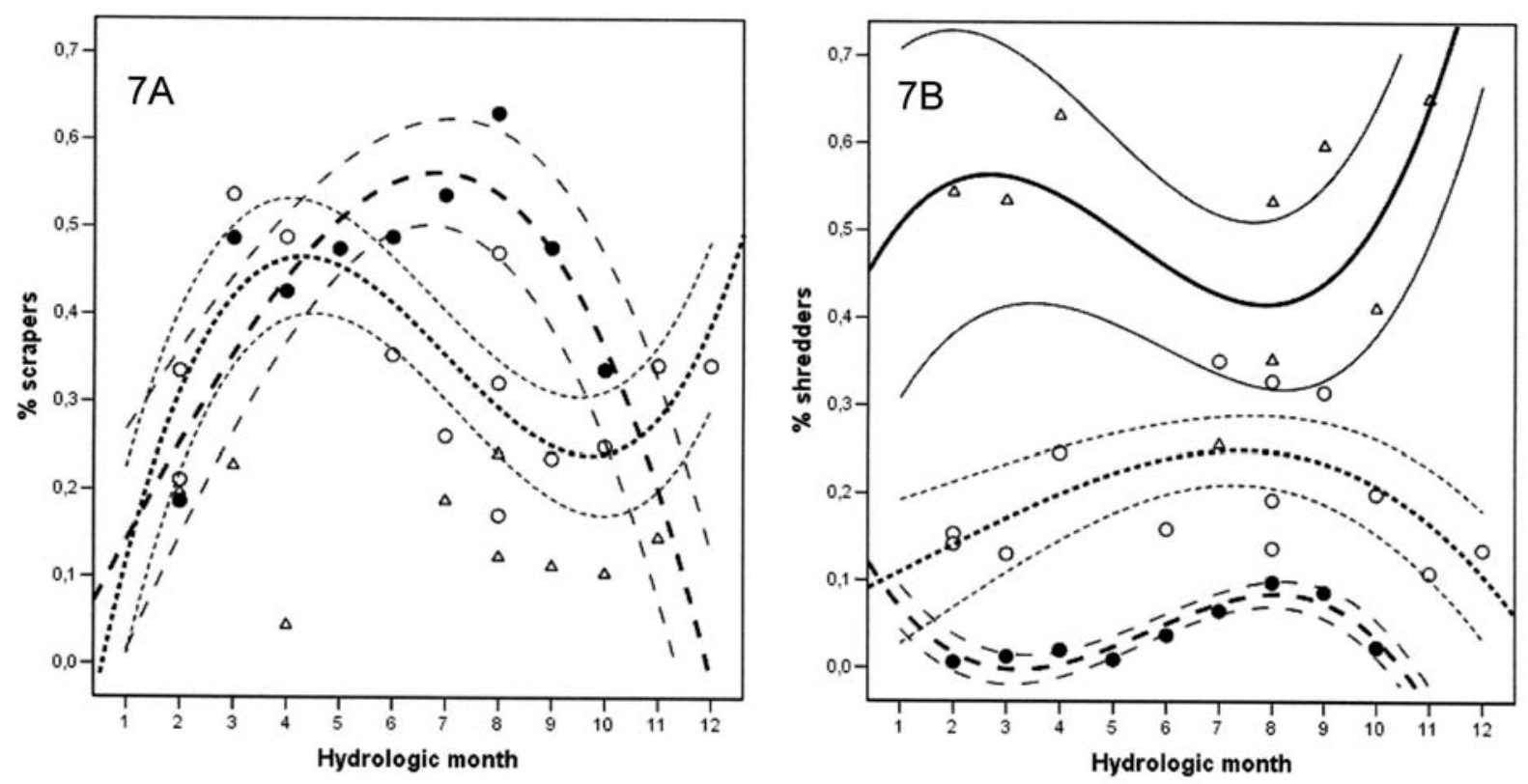

$$
\triangle \mathrm{LC} 1-\circ \mathrm{LC} 2 \cdots \cdots \cdots \cdot \mathrm{GB}^{--\cdot}
$$

Figure 7. Dynamics of scrappers (7A) and shredders (7B) in two Atlantic coastal streams $(\mathrm{LC} 1=\Delta \& \mathrm{LC} 2=0)$ and in one Mediterranean stream $(\mathrm{GB}=\bullet)$. Hydrologic months are $1=$ October until $12=$ September. Dinámica de raspadores $(7 \mathrm{~A})$ y desmenuzadores $(7 B)$ en los dos ríos atlánticos costeros $(L C 1=\Delta \& L C 2=0)$ y en un río mediterráneo $(G B=\bullet)$. Los meses hidrológicos son $1=$ octubre, hasta $12=$ septiembre.

dynamics fitted to quadratic and cubic distributions $(p<0.05)$ (Fig. 7). Percentage of collectorgatherers tended to be low in autumn for LC2 and in summer for LC1, whereas filter-feeders showed an increase in representation in springsummer months. Scrapers showed a cubic S shaped trend with a maximum value of $53 \%$ in winter for LC2, while no significant trend was observed for LC1 (Fig. 7a). Predators showed a peak of maximum representation at the end of the spring (in June, they made up $11 \%$ and $22 \%$ of total FFG abundance in LC2 and LC1 respectively). Shredders showed opposite dynamics in the headwater stream (LC1) and in the second order stream (LC2) (Fig. 7b). In LC1, the highest shredder representation in Atlantic streams, showed a maximum ( $>50 \%)$ of shredders between August and January, when litter inputs and BOM tend to be maximum. However, the bell-shaped curve described by shredders in LC2, with maximum representation in spring, may reflect the seasonal pattern of green alder leaves entering this reach, which has a better developed riparian alder dominated corridor than the upstream site (LC1), which is accompanied by sparse vegetation of Salix spp. adjoined by grasslands (Pardo, 1992). In the forested reach (LC2), spring-summer consumption of mostly green leaves will impulse shredders production after the winter shortage of resources (López et al., 2001). However, at the end of summer and in the beginning of autumn when rainfall levels increase, the rising water levels contribute to the physical abrasion and transport of leaves and individuals within the channel (López et al., 2001).

In the Mediterranean temporary stream (GB) the dynamics followed by the different FFG were significatively fitted to cuadratic and cubic distributions $(p<0.05)$. The relative abundance of collector-gatherers followed a U-shaped curve with maxima at the beginning and the end of the flow season, where they made up respectively $68 \%$ and $57 \%$ of total FFG abundance. Moreover, scrapers, which were maintained over $40 \%$ for most of the year, showed the 
opposite temporal dynamic, represented by a hump-shaped curve (Fig. 7a), thus reaching their minimum representation at the beginning and at the end of the flow period, where they represented respectively $10 \%$ and $34 \%$ of total FFG abundance. The relative abundance of filter-feeders tend to be higher at the beginning of the flow period, and only the relative abundance of shredders and predators increased significantly over the flow period (Fig. 7b). The disappearance of water in the temporary stream at the beginning of the summer, caused a sudden mortality of shredders, which otherwise in a wetter year should be expected to continue consuming litter during autumn-winter months (Álvarez, 2004). Moreover, as shown in other studies conducted in temporary streams (e.g., Boulton \& Lake, 1992), predator densities increase with flow reduction at the end of the study period, when discharge is lower and invertebrate distribution becomes more concentrated (Álvarez, 2004).

The annual hump-shaped curves described by monthly densities of shredders in the Atlantic forested stream and by scrapers in the Mediterranean temporary stream and the semi-annual distribution followed by scrapers in the Atlantic LC2 indicate that both groups may be seasonally limited by resource availability. In the Atlantic forested streams, the supply of allochthonous and autochthonous food sources is discontinuous half of the year, thus dynamics of relative abundance of functional feeding groups in these systems may reflect the phenology of energy sources availability. However, a recent study in the Gorg Blau showed no relation between the relative abundance of detritus feeding invertebrates (collectors or shredders) or grazers and their food supplies (Álvarez, 2004), thus food may be in continuous supply in these temporary systems. The main constraints on the trophic composition of the macroinvertebrate community in GB are related with the resumption or reduction of water flow that characterize temporary streams (Álvarez, 2004) and the associated alteration in habitat structure and availability (Lake, 2003).

\section{CONCLUSION: ECOSYSTEMS GENERALIZATIONS}

1. Climate promotes the availability and dynamics of food resources in the studied stream ecosystems:

1.1. In Atlantic temperate streams, inputs of food resources are discontinuous, due to a clear seasonal (summer-autumn) pattern of production. In these systems, allochtonous inputs, in the form of nutritious leaves, dominate from June to December, thus shading by the riparian vegetation simultaneously influences autochtonous production. As a consequence, autochthonous resources are relatively low over the year, slightly increasing in spring-summer months.

1.2. Mediterranean streams receive high inputs of solar radiation, thus increasing the importance of authoctonous production and plant-herbivore interactions compared to temperate Atlantic streams with closer canopies. A continuous supply of allochtonous resources along the year, of otherwise very low quality, may initially create resource bottleneck for detritivore shredders, thus explaining low abundances of this $\mathrm{FFG}$ in the beginning of the flow period. Therefore, allochtonous resources may be a seasonal alternative and less important energy pathway to consumers.

2. Temporary streams have a high retentive capacity. They accumulate large quantities of allochthonous material despite low input. Regardless of high retention values in Atlantic streams, standing stocks of organic matter are low, even during the major input season, pointing at the influence of biotically mediated higher processing rates coupled with physical processes in these streams.

3. Conditioning and processing of allochthonous materials is re-initiated once flow is resumed in temporary streams, probably needing longer times that the mean annual water period, before they are fully conditioned, therefore usually constituting an alter- 
native food resource. Leaf processing in fast flowing Atlantic streams is a fast process occurring in approximately less than 2 months. Green leaves input of alder from the beginning of summer constitutes nutrient-rich materials to which shredders may adapt due to benign flow conditions during these predictable food supplies. It is to be expected that secondary production will be promoted during spring-summer after winter shortage of resources.

4. High densities of macroinvertebrates in the torrent Gorg Blau are explained by the following factors, fast rates of autochtonous production, close proximity to spring refugia, reduced predator pressure and the low competition, coupled with fast invertebrate colonization, which occurs 1-2 month after flow resumes (Álvarez, 2004; Álvarez \& Pardo, 2005). In fact, high densities and sustained feeding by the dominant grazers were the most important factors depleting periphyton biomass in the Mediterranean temporary stream.

5. In Atlantic streams, low invertebrate densities relate with low resources amounts and limited availability on a seasonal basis, probably pointing at a seasonal bottom-up control of shredders and scrapers by food resources and prolonged adverse hydrodynamic conditions. Moreover, the presence of large predators in these small streams (primarily trout) may indicate a top-down control during benign flow periods.

\section{FUTURE RESEARCH}

It is recommended that a main line of research in both Atlantic and Mediterranean streams should focus on improving the understanding of the functioning of aquatic communities in both systems. Based on the above findings and observations we expect to conduct experiments on the mechanisms underlying predation, competition and resource-consumer interactions across stream types.

The analysis of benthic energy budgets or energy flow through food webs should provide a more precise determination of the importance of autotrophic and heterotrophic food resources in streams with different riparian vegetation (e.g., deciduous vs. ever green) and flow permanence (temporary vs. permanent).

Temporary streams are also good environments for studying patterns of colonization and community succession, as well as the function and adaptation mechanisms of their fauna. Within this line, studies will address the mechanisms allowing maintenance of temporary stream populations when facing disturbances (reproduction patterns of oviposition behaviour, egg hatching, diapause, mortality and emergence), as well as the determination of the importance of the hyporheic zone as refugia.

\section{ACKNOWLEDGEMENTS}

We would like to thank the editors Joan Armengol for his kind invitation to participate in this special volume dedicated to the Dr. Margalef. The data base analysed in this article reflects the help and support of many people and institutions. Some people were technicians who helped with sample collection and analysis (Mar, specially); others were past fellows in the lab who conducted data compilation and analysis and supported some methods (Eva, Núria, Carmen), and some others were instrumental in dealing with language issues and presentation (thanks Asger!). Several funds contributed to the realization of the works involved, FEDER (1DF971481-C02-02), (XUGA29106A96) from Xunta of Galicia, and a research grant from the University of Vigo. The work conducted on Majorca was partially supported by a grant from the Spanish Education Council (HID98-0323C05-02) as part of the project GUADALMED.

\section{REFERENCES}

ÁLVAREZ, M. 2004. Ecología de los ríos temporales de la isla de Mallorca. Ph. D. Thesis. Univ. de Vigo. Spain. 174 pp.

ÁlVAREZ, M. \& I. PARDO. 2005. Life history and production of Agapetus quadratus (Trichoptera: 
Glossosomatidae) in a temporary spring-fed stream. Freshwat. Biol., 50: 930-943.

ALVAREZ-COBELAS, M., C. ROJO \& D. G. ANGELER. 2005. Mediterranean limnology: current status, gaps and the future. J. Limnol., 64, 13-29.

BELlOT, J., J. R. SÁNCHEZ, M. J. LLEDÓ, P. MARTÍNEZ \& A. ESCARRÉ. 1992. Litterfall as a measure of primary production in Mediterranean Holm-oak forest. Vegetatio, 99/100: 69-76.

BIGGS, B. J. F. 1996. Patterns in benthic algae of streams. In: Algal ecology: freshwater benthic ecosystems. R.J. Stevenson, M.L. Bothwell \& R.L. Lowe (eds.): 31-56. Academic Press, San Diego, USA.

BOTT, T. L., J. T. BROCK, C. E. CUSHING, S. V. GREGORY, D. KING \& R. C. PETERSEN. 1978. A comparison of methods for measuring primary productivity and community respiration in streams. Hydrobiologia, 60: 3-12.

BOULTON, A. J. \& P. S. LAKE. 1992. The ecology of two intermittent streams in Victoria, Australia II. Comparisons of faunal composition between habitats, rivers and years. Freshwat. Biol., 27: 99-121.

BUSSOTTI, F., F. BORGHINI, C. CELESTI, C. LEONZIO, A. COZZI, D. BETTINI \& $\mathrm{M}$. FERRETTI. 2003. Leaf shedding, crown condition and element return in two mixed holm oak forests in Tuscany, central Italy. Forest Ecology and Management, 176: 273-285.

CATTANEO, A., G. SALMOIRAGHI \& S. GAZZERA. 1995. The rivers of Italy. In: Ecosystems of the world, River and stream ecosystems. C. E. Cushing, K. W. Cummins \& G. W. Minshall (eds.): 479-505. Elsevier, Amsterdam, The Netherlands.

CHERBUY, B., R. JOFFRE, D. GILLON \& S. RAMBAL. 2001. Internal remobilization of carbohydrates, lipids, nitrogen and phosphorus in the Mediterranean evergreen oak Quercus ilex. Tree Physiology, 21: 9-17.

CILleRO, C., I. PARDO \& E. LÓPEZ. 1999. Comparisons of riparian vs. over stream trap location in the estimation of vertical litterfall inputs. Hydrobiologia, 416: 171-179.

CILLERO, C. 2001. Evaluación del estado de los bosques de ribera y su influencia en el funcionamiento de las cabeceras fluviales. Consideraciones para su gestión. Proyecto fin de carrera, Ingeniero Forestal. Universidad de Santiago. Spain. 136 pp.
CUMMINS, K. W. 1962. An evaluation of some techniques for the collection and analysis of benthic samples with special emphasis on lotic waters. American Midland Nauralist, 67: 477-504.

CUMMINS, K. W. 1973. Trophic relations of aquatic insects. Annual Review of Entomology, 18: 183-206.

CUMMINS, K. W., M. A. WILZBACH, D. M. GATES, J. B. PERRY \& W. B. TALIAFERRO. 1989. Shredders and riparian vegetation. BioScience, 39: 24-30.

DEL ROSARIO, R. B. \& V. H. RESH. 2000. Invertebrates in intermittent and perennial streams: Is the hyporheic zone a refuge from drying? J. N. Amer. Benthol. Soc., 19: 680-696.

DELUCCHI, C. M. 1988. Comparision of community structure among streams with different temporal flow regimes. Can. Jour. of Zool., 66: 579586.

DELUCCHI, C. M. 1989. Movement patterns of invertebrates in temporary and permanent streams. Oecologia, 78: 199-207.

DIETERICH, M. \& N. H. ANDERSON. 1998. Dynamics of Abiotic Parameters, Solute Removal and Sediment Retention in Summer-Dry Headwater Streams of Western Oregon. Hydrobiologia, 379: 1-15.

DIETERICH, M. \& N. H. ANDERSON. 2000. The invertebrate fauna of summer-dry streams in western Oregon. Arch. Hydrobiologie, 147: 273-295.

ELOSEGUI, A. \& J. POZO. 1998. Epilithic biomasa and metabolism in a north Iberian stream. Aquat. Sci., 60: 1-16.

FANO, E. A., L. CASTELNOUVO, M. COLANGELO, E. MARCHETT, J. G. MORGANA, G. PUPPI \& M. ZAMORANI. 1988. Decomposition process Quercus ilex leaves in Mignone River. Italy. Museo di Storia Naturale della Lunigiana, 6/7: 127-131.

FEMINELLA, J. W. 1996. Comparison of benthic macroinvertebrate assemblages in small streams along a gradient of permanence. J. N. Amer. Benthol. Soc., 15: 651-669.

GARCÍA-AVILÉS, J. 1990. Insectos acuáticos de Baleares. Odonata, Ephemeroptera, Heteroptera, Plecoptera y Coleoptera. Ph.D. Thesis. Universidad Complutense de Madrid. 595 pp.

GASITH, A. \& V. H. RESH. 1999. Streams in mediterranean climate regions: abiotic influences and biotic responses to predictable seasonal events. Ann. Rev. Ecol. System., 30: 51-81.

GESSNER, M. O. \& E. CHAUVET. 1994. Importance of stream microfungi in controlling breakdown rates of leaf litter. Ecology, 75: 1807-1817. 
HYNES, H. B. N. 1970. The Ecology of Running Waters. University of Toronto Press, Toronto, Ontario. 555 pp.

LAKE, P. S. 2000. Disturbance, patchiness, and diversity in streams. J. N. Amer. Benthol. Soc., 19: 573-592.

LAKE, P. S. 2003. Ecological effects of perturbation by drought in flowing waters. Freshwat. Biol., 48: 1161-1172.

LAMBERTI, G. A., \& S. V. GREGORY. 1996. Transport and retention of CPOM. In: Methods in Stream Ecology. F.R. Hauer \& G.A. Lamberti (eds.): 217229. Academic Press, San Diego, California, USA.

LOHMAN, K., J. R. JONES \& B. D. PERKINS. 1992. Effects of nutrient enrichment and flood frequency on periphyton biomass in northern Ozark streams. Can. J. Fish. Aquat. Sci., 49: 1198-1205.

LÓPEZ, E. S., N. FELPETO \& I. PARDO. 1997. Comparison of methods to study the processing of Alnus glutinosa and Eucaliptus globulus leaves in a forested headwater stream. Limnetica, 13: 13-18.

LÓPEZ, E. S., I. PARDO \& N. FELPETO. 2001. Seasonal differences in green leaf breakdown and nutrient content of deciduous and evergreen tree species and grass in a granitic headwater stream. Hydrobiologia, 464: 51-61.

LORENZEN, C. J. 1967. Determination of chlorophyll and phaeopigments: spectrophotometric equations. Limnol. Oceanogr., 12: 342-346.

MAAMRI, A., H. CHERGUI \& E. PATTEE. 1997. Leaf litter processing in a temporary northeastern Moroccan river. Arch. Hydrobiol., 140: 513-531.

MINSHALL, G. W. 1984. Aquatic insect-substratum relationships. In: The ecology of aquatic insects. V.H. Resh \& D.M. Rosenberg (eds.): 358-400. Praeger Publishers, New York, USA.

MOLLES, M. C. 1999. Ecology: Concepts and applications. MacGraw-Hill. Boston, USA 509 pp.

MONK, C. D. 1966. An ecological significance of evergreenness. Ecology, 47: 504-505.

MUÑOZ, I. 2003. Macroinvertebrate community structure in an intermittent and a permanent Mediterranean streams in NE Spain. Limnetica, 22: 107-116.

PARDO, I. 1992. Estudio comparado de la macrofauna bentónica (ambientes lóticos) de los ríos Louro y Te. (Pontevedra). Ph.D. Thesis, Universidad de Santiago de Compostela. Spain. 443 pp.
PARDO, I. 1995. Comparative water quality characterisation by PCA of an unperturbed and a polluted stream. Arch. Hydrobiol., 132: 95-114.

PARDO, I. 2000. Patterns in community assembly in a four order stream. Arch. Hydrobiol., 148: 301-320.

SCHWARZ, A. E. \& J. SCHWOERBEL. 1997. The aquatic processing of sclerophyllous leaves on a Mediterranean island, Corsica: spatial and temporal pattern. Annals de Limnologie, 33: 107-119.

QUISPEL, A., C. RODRÍGUEZ-BARRUECO \& N. S. SUBBA RAO. 1993. Some general considerations on symbioses of nitrogen-fixing trees. In: Symbioses in nitrogen-fixing trees. N. S. Subba Rao \& C. Rodríguez-Barrueco (eds.): 1-32. International Science Publisher, New York, USA.

RAPP, M. \& S. LEONARDI. 1988. Litter decomposition during one year in a holm oak Quercus ilex stand. Pedobiologia, 32: 177-185.

ROSEMOND, A. D. 1994. Multiple factors limit seasonal variation in periphyton in a forest stream. $J$. North Am. Benthol. Soc., 333-344.

ROUNICK, J. S. \& M. J. WINTERBOURN. 1983. The formation, structure and utilization of stone surface organic layers in two New Zealand streams. Freshwat. Biol., 13: 57-72.

SABATER, S., S. V. GREGORY \& J. R. SEDELL. 1998. Community dynamics and metabolism of benthic algae colonizing wood and rock substrata in a forest stream. J. Phycol., 34: 561-567.

TERRADAS, J. 2001. Ecología de la vegetación. De la ecofisiología de las plantas a la dinámica de comunidades y paisajes. Ed. Omega. Barcelona. 773 pp.

VIDAL-ABARCA, M. R., M. L. SUÁREZ \& L. RAMÍREZ-DÍAZ. 1992. Ecology of spanish semiarid streams. Limnetica, 8: 151-160.

VIVAS, S. 2003. Comunidades de macroinvertebrados de los ríos Aguas y Almanzora: relaciones con la evaluación del estado ecológico. Ph.D. Thesis, Universidad de Almería. 222 pp.

WEBSTER, J. R., A. P. COVICH, J. L. TANK \& T. V. CROCKETT. 1994. Retention of coarse organic particles in streams in the southern Appalachian Mountains. J. N. Amer. Benthol. Soc., 13: 140-150.

WILLIAMS, D. D. 1996. Environmental constraints in temporary waters and their consequences for insect fauna. J. N. Amer. Benthol. Soc., 15: 634-650. 